\title{
$\mathrm{Al}-\mathrm{Ti}$ 混合硫酸塩溶液からの共沈物の水熱条件下における結晶化
}

\author{
服部豪夫・伏井康人・毛利純一・吉村昌弘*・宗宮重行* \\ 千葉大学 工学部 工業化学科
*東京工業大学 工業材料研究所
}

\begin{abstract}
硫酸アルミニウムを硫酸チタンの混合溶液から水酸化アンモニウムで沈殿させた $\mathrm{Al}-\mathrm{Ti}$ 共沈水 和物を出発物質に用い，これを水熱条件下（温度 $100^{\circ} \sim 700^{\circ} \mathrm{C}$ ，圧力 $10 \mathrm{MPa}$ 及び $100 \mathrm{MPa}$ ，反 応時間 $0 \sim 72 \mathrm{~h}$ ) で処理して, その生成結晶を調べた. $100 \mathrm{MPa}, 24 \mathrm{~h}$ の場合, $100^{\circ} \sim 400^{\circ} \mathrm{C}$ でベー マイトとアナターゼが結晶化した。ベーマイトは $500^{\circ} \mathrm{C}$ でコランダムに変化したが，アナターゼ からルチルへの変化が明確になるのは $650^{\circ} \mathrm{C}$ 以上であった。 $10 \mathrm{MPa}, 24 \mathrm{~h}$ の場合, チ夕ニア端成 分では $100^{\circ} \sim 700^{\circ} \mathrm{C}$ でアナターゼのみが同定された。アルミナ端成分は, $100^{\circ} \sim 300^{\circ} \mathrm{C}$ でベーマイ 卜が， $400^{\circ} \sim 500^{\circ} \mathrm{C}$ ではアルミナ-硫酸アンモニウム化合物が， $600^{\circ} \sim 700^{\circ} \mathrm{C}$ ではコランダムが結晶 化した。共沈水和物を水酸化ナトリウム $0.2 \sim 10 \mathrm{wt} \%$ 溶液で洗浄すると, $500^{\circ} \mathrm{C}, 100 \mathrm{MPa}, 24 \mathrm{~h}$ の処理により，ナトリウムーチタニア化合物が生成した．同様に水酸化リチウム溶液を使って処理 するとリチウムーチタニア化合物を得た。本実験条件ではアルミナとチタニアの化合物は生成せず, チタン酸アルミニウム $\left(\mathrm{Al}_{2} \mathrm{TiO}_{5}\right)$ はアナターゼとコランダムに分解した。（1984 年 4 月 11 日受付）
\end{abstract}

\section{Hydrothermal Crystallization of Co-precipitated Hydrous Oxides from Al-Ti Sulfate Solution}

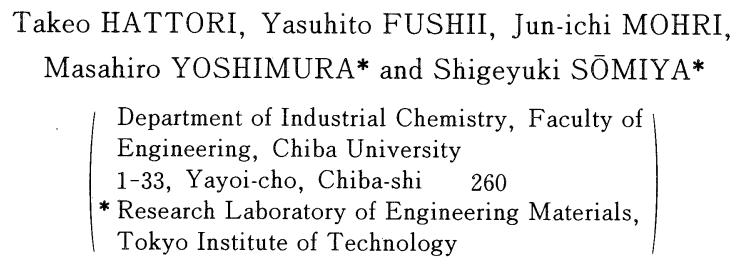

Hydrothermal crystallization of $\mathrm{Al}-\mathrm{Ti}$ hydrous oxides with the ratio of $\mathrm{Al}_{2} \mathrm{O}_{3} / \mathrm{TiO}_{2}=1$ coprecipitated from a sulfate solution containing constituent ions by ammonium hydroxide was studied between $100^{\circ}$ and $700^{\circ} \mathrm{C}$, at 10 and $100 \mathrm{MPa}$, for $0-72 \mathrm{~h}$. When treated at $100 \mathrm{MPa}$ for $24 \mathrm{~h}$, boehmite and anatase crystallized at $100^{\circ}-400^{\circ} \mathrm{C}$. Boehmite changed to corundum at $500^{\circ} \mathrm{C}$, while anatase changed to rutile at $650^{\circ} \mathrm{C}$. Treatment of co-precipitates at $10 \mathrm{MPa}$ for 24 h yielded only anatase as for titania between $100^{\circ} \mathrm{C}$ and $700^{\circ} \mathrm{C}$, while alumina component crystallized as boehmite at $100^{\circ}-300^{\circ} \mathrm{C}$, alumina-ammonium-sulfate hydroxide compounds at $400^{\circ}-500^{\circ} \mathrm{C}$, and corundum at $600^{\circ}-700^{\circ} \mathrm{C}$, respectively. When the co-precipitated hydrous oxides were washed with $0.2-10 \mathrm{wt} \%$ sodium hydroxide solution, sodium titanate was formed by treatment at $500^{\circ} \mathrm{C}$ and $100 \mathrm{MPa}$ for $24 \mathrm{~h}$. Similarly, the hydrothermal treatment with lithium hydroxide solution yielded lithia-titania compounds. Under the hydrothermal conditions studied, no intermediate compounds between alumina and titania were produced. Moreover, aluminum titanate $\left(\mathrm{Al}_{2} \mathrm{TiO}_{5}\right)$ synthesized in air was decomposed into anatase and corundum under the same conditions.

[Received April 11, 1984]

Key-words : Hydrothermal crystallization, Al-Ti hydrous oxides, Rutile, Anatase, Corundum, Boehmite

\section{1. 緒言}

アルミナーチタニア系材料は, 耐火物, 熱交換器材料, 研磨剂等への応用例がある．特にこの系の化合物である チタン酸アルミニウムは高融点，低熱膨張率のため耐熱
衝撃性に優れている点が注目されている.

アルミナーチタニア系の研究は，Lang ら ${ }^{1}$ が状態図を 定めて以来多くの報告がある. 我が国でも, 野口ら ${ }^{21}$, 永廣ら ${ }^{3)}$, 加藤ら ${ }^{4)}$, 浜野ら ${ }^{5}$ により, 主にチタン酸アル 
ミニウムの合成や焼結の研究がなされてきた.これら固 相法を用いた研究のほかに, 近年は気相法を用いた報告 例もあり, Gani ら ${ }^{6)}$ や加藤ら ${ }^{7)}$ はハロゲン化物を気相中 で酸化してアルミナーチタニア系微粉体を得ている.

均一混合粉体は, これら気相法や共沈法のほかに水熱 法によっても合成することができる. 合金と高温高圧水 とを反応させる水熱酸化法によりアルミナージルコニア ${ }^{8), 9)}$, アルミナーハフニア10)の混合微粉体が生成されている. このほかに, 出発物質に非晶質や低結晶性沈殿を用いる 水熱結晶化法 ${ }^{11), 12)}$ がある.この方法では比較的低温にお いて結晶性の非凝集性粉体が得られ, 粒度分布や結晶の 形態等を制御できる特色がある ${ }^{13)}$.

水熱条件下でのアルミナやチタニア単独の挙動につい ては多数の報告がある. 例えばアルミナでは Laubengayer $ら^{14)}$, Cooke $ら^{15)}$, Ervin $ら^{16)}$, Roy $ら^{17)}$, Newsome $ら^{18)}$, Druzhinina ${ }^{19)}$, Kennedy ${ }^{20)}$, Torkar $ら^{21)}$ によって $\kappa_{1}-\mathrm{Al}_{2} \mathrm{O}_{3}$, Reactive $\alpha-\mathrm{Al}_{2} \mathrm{O}_{3}$ や Autoclave $\gamma$ $\mathrm{Al}_{2} \mathrm{O}_{3}$ などの準安定相を含む各相の生成領域が定められ ている. チタニアに関しても太田, 斎藤ら ${ }^{22) ~ 24)}$ の一連 の研究のほか井本ら ${ }^{25)}$, 泉 ${ }^{26)}$, 藤木ら ${ }^{27)}$ がアナターゼ, ルチル, ブルッカイト各相の生成や結晶成長について報 告している. しかし水熱条件下におけるアルミナ-チ夕 ニア系の報告例はほとんどない。本研究の目的はアルミ ナーチタニア系非晶質共沈水和物を水熱条件下で結晶化 させ,アルミナーチタニア混合微粉体の生成を検討する ことである。

\section{2. 実験}

$\mathrm{Al}_{2}\left(\mathrm{SO}_{4}\right)_{3} \cdot 14 \sim 18 \mathrm{H}_{2} \mathrm{O}$ (試薬特級*) $1.0 \mathrm{M}$ 溶液と硫 酸チタン(試薬*) $1.7 \mathrm{M}$ 硫酸溶液を酸化物換算で $1: 1$ に混合した。過剩の水酸化アンモニウム（試薬特級*) $25 \mathrm{wt} \%$ 溶液に, この混合溶液を加えて生じた沈殿を $90^{\circ} \mathrm{C}$ で 58 日間乾燥させて共沈試料とした。 これを水又 は水酸化ナトリウム $0.2 \sim 10 \mathrm{wt} \%$ 溶液で洗浄し, $120^{\circ} \mathrm{C}$ で 1 日乾燥した武料あるいはアークイメージ炉で溶融し て粉砕した試料も出発物質とした。

水熱処理の条件は, 温度 $100^{\circ} \sim 700^{\circ} \mathrm{C}$, 圧力 10 又は $100 \mathrm{MPa}$ 反応時間 0 〜2 $\mathrm{h}$ であった. 試料は水や水酸 化リチウム 6 及び $17 \mathrm{wt} \%$ 溶液, フッ化ナトリウム 4 $\mathrm{wt} \%$ 溶液, 水酸化アンモニウム $25 \mathrm{wt} \%$ 溶液とともに 金容器中に溶封して圧力容器内に入れ, 圧力容器に水を 注入後加熱加圧した。装置は日機装製水熱合成装置 THP-A II 型を用い, 温度は圧力容器外側の, 金容器上 部と底部位置のプラチネル熱電対で測定した. 所定時間 の反応後, 圧力容器は水に浸して急冷し, 生成物を金容 器から洗い出して, そのまま $120^{\circ} \mathrm{C}$ で乾燥した.

出発試料及び生成物は粉末 X 線回折法によって相の $*$ 和光純薬工業 $($ 株)
同定, 定量分析, 結晶子径を測定した. 測定には理学電 機製ロータフレックス RU-200X を使用し, $\mathrm{Cu} K \alpha$ 線 でカーボンモノクロメーターを用いた．定量分析と結晶 子径測定ではベーマイト (120), コランダム (024), ア ナターゼ (101) と (200), ルチル (110) の各反射面を $0.02^{\circ}$ 間隔で各々 $10 \sim 80 \mathrm{~s}$ の定時計測を行った.

定量分析ではベーマイト, コランダム, アナターゼ, ルチルをそれぞれ所定の割合で混合し検量線を作った。

結晶子径測定では標準物質として二酸化ケイ素（和光純 薬工業最純）を用いて各ピークの真の回折線プロフィル を求め ${ }^{28)}$, その積分幅から決定した。

また, 出発試料や生成物は日本電子製 JSM-T 200 走 査型電子顕微鏡 (SEM) を用いて粒子の大きさや形状 等を観察し, SED 880 エネルギー分散分析装置を用い て生成相の元素分析を行った。

\section{3. 結果と考察}

\section{1 生成相に及ぼす温度の影響}

共沈試料は $\mathrm{X}$ 線的には非晶質である（図1）。これを $100^{\circ} \sim 700^{\circ} \mathrm{C}, 100 \mathrm{MPa}$ 下において水熱処理して生成相 に及ぼす温度の影響を調べた。

試料中のアルミナ成分は $100^{\circ} \sim 400^{\circ} \mathrm{C}$ ではベーマイト として結晶化したが， $500^{\circ} \mathrm{C}$ 以上では，これが消失して コランダムが生成していた（図２）.チタニア成分は

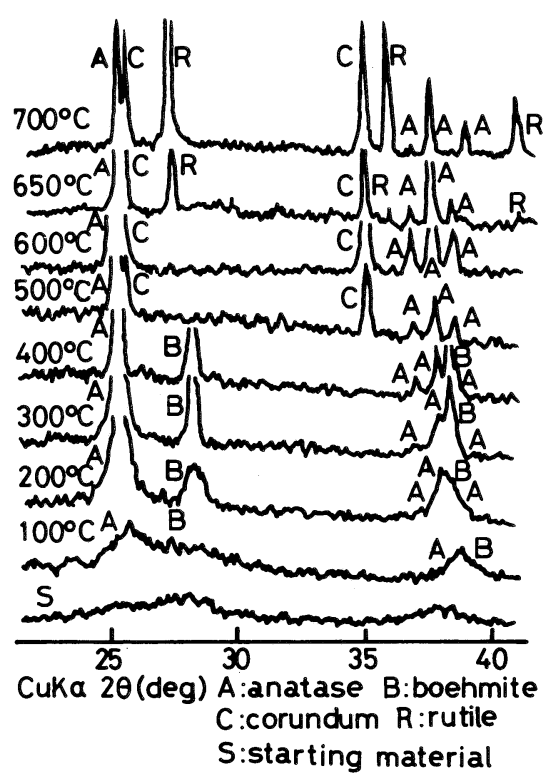

Fig. 1. X-ray powder patterns of the products by hydrothermal crystallization of co-precipitated Al- Ti hydrous oxides (including $\left.\left(\mathrm{NH}_{4}\right)_{2} \mathrm{SO}_{4}\right)$ at various temperatures, under $100 \mathrm{MPa}$, for $24 \mathrm{~h}$ (Starting materials and samples after hydrothermal crystallization were washed by water, and dried at $120^{\circ} \mathrm{C}$ ) 


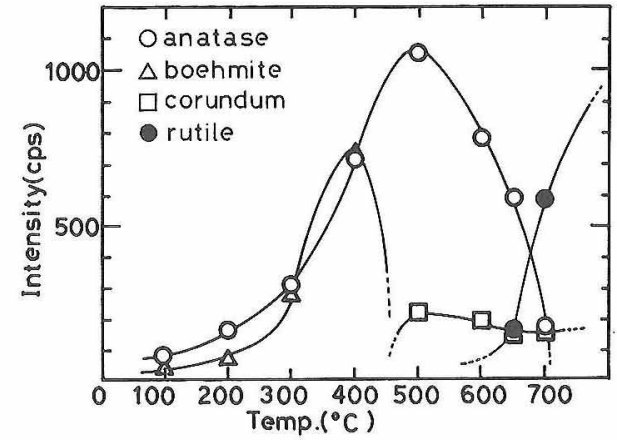

Fig. 2. X-ray peak intensities of the products by hydrothermal crystallization of co-precipitated $\mathrm{Al}$ - Ti hydrous oxides (including $\left.\left(\mathrm{NH}_{4}\right)_{2} \mathrm{SO}_{4}\right)$ at various temperatures, under $100 \mathrm{MPa}$, for $24 \mathrm{~h}$.

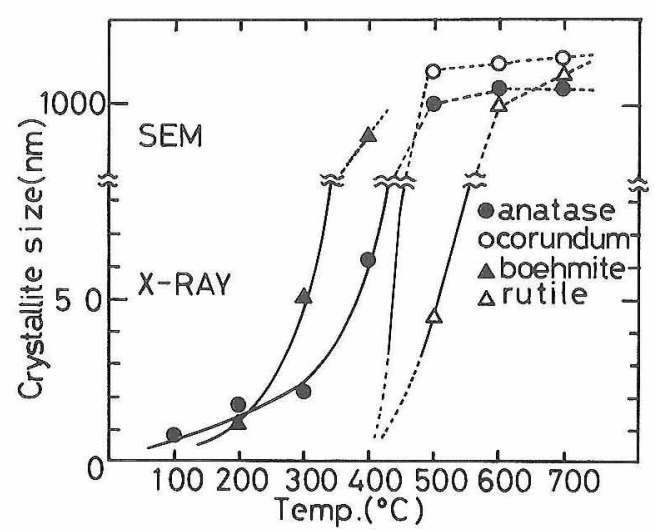

Fig. 3. Relationship between crystallite size and temperature of hydrothermal crystallization of coprecipitated Al-Ti hydrous oxides (including $\left(\mathrm{NH}_{4}\right)_{2}$ $\mathrm{SO}_{4}$ ) under $100 \mathrm{MPa}$, for $24 \mathrm{~h}$.

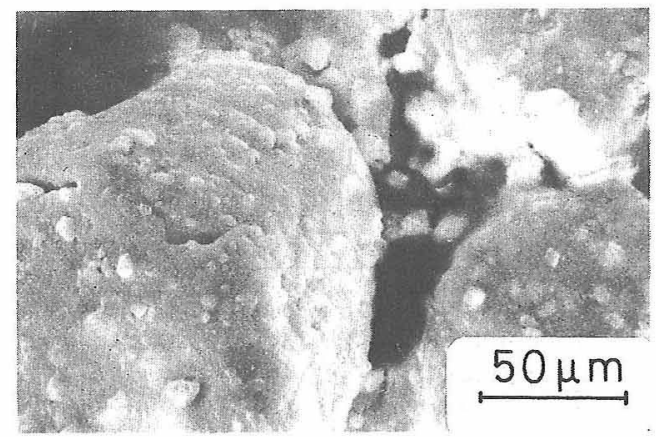

Fig. 4. Aggregated boehmite and anatase crystals crystallized hydrothermally from co-precipitated Al- $\mathrm{Ti}$ hydrous oxides (including $\left.\left(\mathrm{NH}_{4}\right)_{2} \mathrm{SO}_{4}\right)$ at $300^{\circ} \mathrm{C}$, under $100 \mathrm{MPa}$, for $24 \mathrm{~h}$.

$600^{\circ} \mathrm{C}$ までアナタ一ゼとして結晶化し， $650^{\circ} \mathrm{C}$ からは チルへと変化した。このためアルミナーチタ二ア両成分

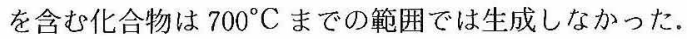

これらの生成物の結晶子径の測定を行って各相の結晶

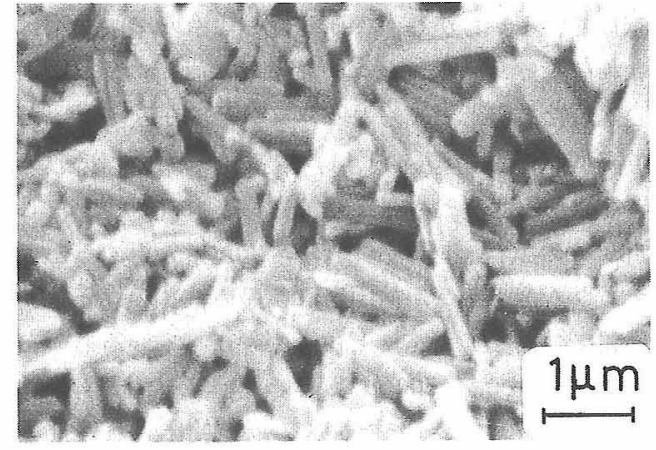

Fig. 5. Boehmite crystals crystallized hydrothermally from co-precipitated Al-Ti hydrous oxides (including $\left(\mathrm{NH}_{4}\right)_{2} \mathrm{SO}_{4}$ ) at $400^{\circ} \mathrm{C}$, under $100 \mathrm{MPa}$, for $24 \mathrm{~h}$.

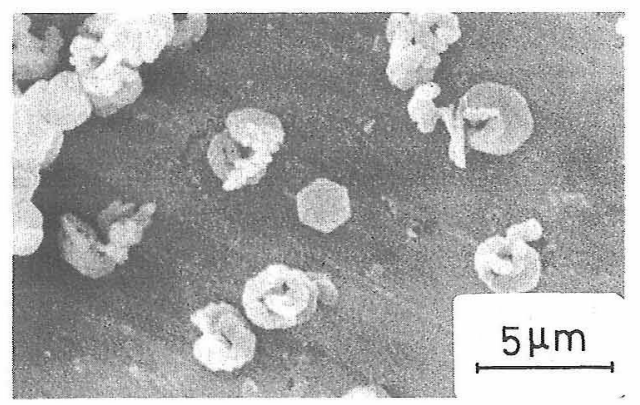

Fig. 6. Corundum crystals crystallized hydrothermally from co-precipitated $\mathrm{Al}-\mathrm{Ti}$ hydrous oxides (including $\left.\left(\mathrm{NH}_{4}\right)_{2} \mathrm{SO}_{4}\right)$ at $700^{\circ} \mathrm{C}$, under $100 \mathrm{MPa}$, for $24 \mathrm{~h}$.

化温度を調べた（図３）, 結晶子が急速に成長する温度 はベーマイトで $300^{\circ} \mathrm{C}$ 以上，アナターゼで $400^{\circ} \mathrm{C}$ 以上,

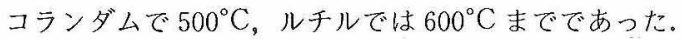

図 4 に示すように $300^{\circ} \mathrm{C}$ 以下の温度で処理した試料 では大きな凝集粒子が多く，1次粒子を見分けるのは困 難であった。しかし $400^{\circ} \mathrm{C}$ になると，幅 $0.2 \sim 0.4 \mu \mathrm{m}$ ， 長さ $1 \mu \mathrm{m}$ 程度の大きさが比較的そろっているべーマイ トの柱状結晶が見られた（図 5 ). X 線による平均結晶 子径も $400^{\circ} \mathrm{C}$ では測定限界 $(150 \mathrm{~nm}$ 程度) 以上に成長 していた。

$500^{\circ} \mathrm{C}$ 以上ではアルミナ成分は六角板状のコランダム 粒子となった。この板状粒子は更に環状の集合粒子を形 成しているものが多く，大きさは $700^{\circ} \mathrm{C}$ の場合で $1 \sim 10$ $\mu \mathrm{m}$ 程度であるが (図 6 )，中には凝集して数十 $\mu \mathrm{m} \omega$ 大きさになっているものもあった。

佐藤ら ${ }^{29}$ はベーマイトが空気中での加熱によって脱水 し $500^{\circ} \sim 1200^{\circ} \mathrm{C}$ における種々の中間相 $(\gamma-, \delta-, \theta-)$ を 経て， $1300^{\circ} \mathrm{C}$ でコランダムの単一相へ変わることを報 告している。また，吉村ら ${ }^{301}$ はアルミニウム金属粉末を $100 \mathrm{MPa}, 500^{\circ} \sim 700^{\circ} \mathrm{C}, 3 \mathrm{~h}$ ，密封系において水熱酸 化すると，コランダムとともに $x_{1}-\mathrm{Al}_{2} \mathrm{O}_{3}$ が生成すると 
報告している. しかし, 本研究ではこれらの中間相は確 認されなかったことからベーマイトは直接コランダムへ と変化したものと考えられる

走査型電子顕微鏡 $(\mathrm{SEM})$ 観察ではチタニア成分は 明確な自形をもった粒子として観察されなかった。しか し $400^{\circ} \mathrm{C}$ の試料（図 5 ）を EDS で元素分析するとアル ミナニウムとチタンが検出されるので柱状のベーマイト 結晶間に微細なアナターゼ粒子が分布しているものと考 えられる.また， $500^{\circ} \mathrm{C}$ 以上で処理した試料中にも EDS の点分析によってチタンのみが検出される部分は 見られなかったことから，チタニアは高温でも凝集が阻 害されていると思われる。これはアルミナ成分とチタ二 ア成分の結晶化温度のずれと共沈試料中の硫酸アンモ二 ウムの存在が原因と考えられる。

結晶相を占める各生成相のモル比を求めた定量分析の 結果（図 7)，400ㄷ 見られアナターゼの割合が次第に増加し， $500^{\circ} \mathrm{C}$ 以上で はアナターゼがルチルに変化している様子が分る. 低温 でベーマイトの比率が高いのは, アナターゼより低い温 度で結晶化するためである。この温度差は図 3 の結晶子 径の測定結果より約 $100^{\circ} \mathrm{C}$ であった. 共沈試料中のア ルミナ成分とチタニア成分は分子レベルで混合している と考えられるので，ベーマイトが先に結晶化するとその 結晶間にチタニア成分が分布することになる.そのため, SEM や EDS で確認できるほど大きな粒子や凝集体の 成長が困難であったと考えられる.

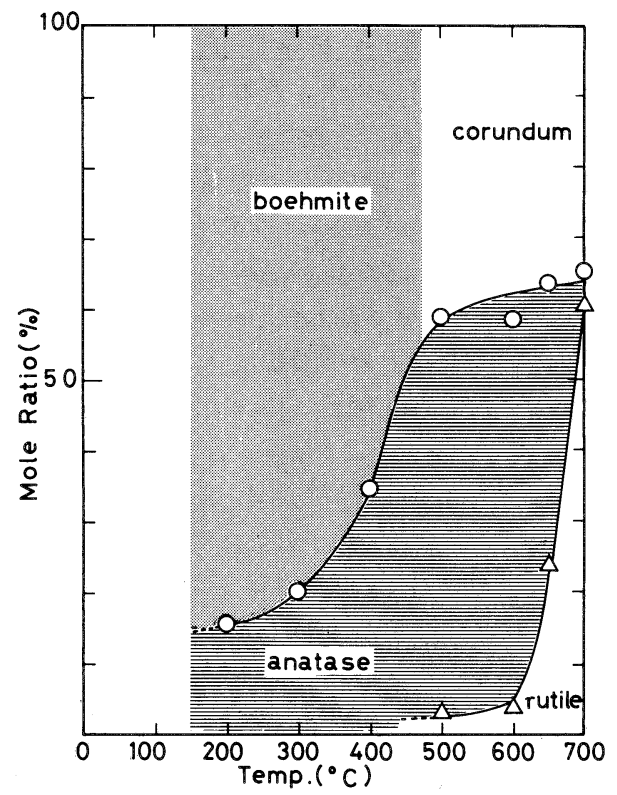

Fig. 7. Relationship between mole ratio and temperature of hydrothermal crystallization of co-precipitated Al-Ti hydrous oxides (including $\left.\left(\mathrm{NH}_{4}\right)_{2} \mathrm{SO}_{4}\right)$ at various temperatures, under 100 $\mathrm{MPa}$, for $24 \mathrm{~h}$.
一方, 黒崎ら ${ }^{31)}$ は, 四塩化チタンを原料とした場合, 硫酸アンモニウムの添加によって未発達のアナターゼ結 晶が生成したと報告している. また, 舟木ら ${ }^{321}$ は, 硫酸 ナトリウム溶液中で生成したチタニア粒子は均一で丸味 を帯びた微粒子となることを電子顕微鏡によって観察し ている. したがって本研究では，共沈試料中に含まれる 硫酸アンモニウムによりチタニア成分の結晶化が抑制さ れてアルミナ成分中に分散したことも考えられる。

硫酸アンモニウムがこの系に及ぼす影響には，アナ ターゼからルチルへの相変化の抑制もある.舟木ら ${ }^{33}$ は, 四塩化チタンの加水分解の際に硫酸アンモ二ウムを添加 するとルチルの生成に顕著な抑制作用を見いだしてい る。また, 泉 ${ }^{26)}$ はチタンエトキシドを純水中で加水分解 した無定形チタン酸を $350^{\circ} \mathrm{C}, 49 \mathrm{MPa}, 70 \mathrm{~h}$ の水熱条 件下で結晶化させたときの生成相は，溶液の $\mathrm{pH}$ と用い る酸の種類によって決まり, 硫酸を用いるとルチルは 0.005 から $0.5 \mathrm{~mol} / 1$ の領域で生成すると報告してい る。

本研究では $100 \mathrm{MPa}, 24 \mathrm{~h}$ の水熱条件下において $500^{\circ} \mathrm{C}$ よりアナターゼからルチルへの相変化が始まり, $650^{\circ} \mathrm{C}$ 以上で明確になった。しかし， $700^{\circ} \mathrm{C}, 150 \mathrm{MPa}$, $72 \mathrm{~h}$ にしても少量のアナターゼが残存していた。藤木 ${ }^{27)}$ はテトライソプロポキシドを加水分解した非晶質チタニ ア水和物を水熱条件下で結晶化させた際に $380^{\circ} \mathrm{C}, 98$ $\mathrm{MPa}$ でもアナタ一ゼはルチルに相転移して行くと報告 している. 泉や藤木の結果に比べ, 本研究のアナターゼ, ルチル間の相変化が高温になっているのは共沈試料中に 副生した硫酸アンモニウムが相変化を抑制した結果と思 われる。

\section{2 生成相に及ぼす圧力の影響}

$100^{\circ} \sim 700^{\circ} \mathrm{C}, 10 \mathrm{MPa}, 24 \mathrm{~h}$ の水熱条件下で共沈試 料を結晶化させた. 生成結晶の量比を調べるため生成相 ごとの回折線の強度を测定し図 8 にその結果を示す。

アルミナ成分は圧力 $100 \mathrm{MPa}$ の場合と同様に, $300^{\circ} \mathrm{C}$ まではベーマイトとして, $600^{\circ} \mathrm{C}$ 以上ではコラン

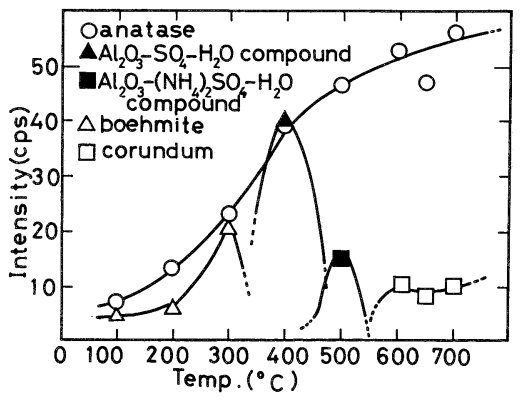

Fig. 8. X-ray peak intensities of the products by hydrothermal crystallization of co-precipitated $\mathrm{Al}-\mathrm{Ti}$ hydrous oxides (including $\left.\left(\mathrm{NH}_{4}\right)_{2} \mathrm{SO}_{4}\right)$ at various temperatures, under $10 \mathrm{MPa}$, for $24 \mathrm{~h}$. 


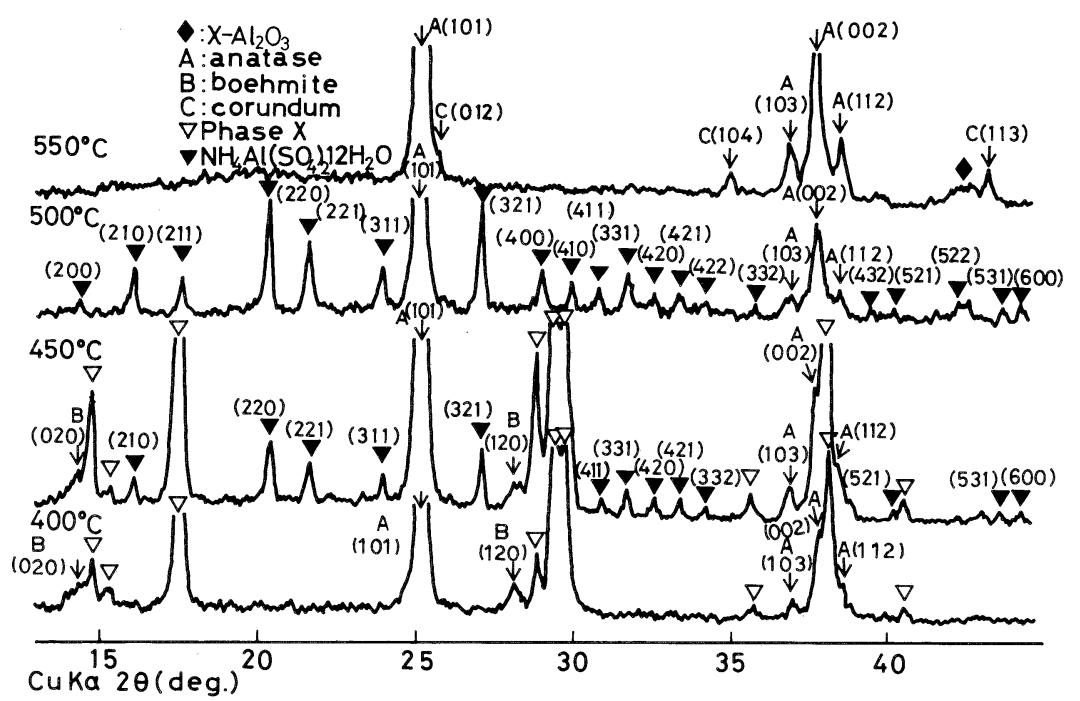

Fig. 9. X-ray powder patterns of the products by hydrothermal crystallization of co-precipitated Al-Ti hydrous oxides (including $\left.\left(\mathrm{NH}_{4}\right)_{2} \mathrm{SO}_{4}\right)$ under $10 \mathrm{MPa}$, for $24 \mathrm{~h}$.

ダムとして結晶化している. しかし， $400^{\circ} \mathrm{C，及び}$ $500^{\circ} \mathrm{C}$ ではこの両者とは異なる回折図形を示す生成物が 現れていた。これは共沈試料中の硫酸アンモニウムがア ルミナ成分と反応して化合物を形成したものと考えられ る.

このアルミナー硫酸アンモニウム-水和物の生成温度範 囲を $50^{\circ} \mathrm{C}$ ごとに調べると，この化合物には $450^{\circ} \mathrm{C}$ 以下 で生成する低温相 $\mathrm{X}$ 上, $450^{\circ} \mathrm{C}$ 以上で生成する高温相 $\mathrm{Y}$ があった（図 9 )。 $\mathrm{Y}$ 相は $\mathrm{NH}_{4} \mathrm{Al}\left(\mathrm{SO}_{4}\right)_{2} \cdot 12 \mathrm{H}_{2} \mathrm{O}^{34)}$ の 回折図形とほぼ一致した。 $\mathrm{Y}$ は $550^{\circ} \mathrm{C}$ ではコランダム と $\chi-\mathrm{Al}_{2} \mathrm{O}_{3}$ に変わっているが, 両者の回折線はブロード で強度も弱い.これは複塩 $\mathrm{Y}$ の分解反応による非晶質 化の過程が存在しているためと思われる.

$\chi-\mathrm{Al}_{2} \mathrm{O}_{3}$ は虎谷ら ${ }^{10)}$ がアルミニウム金属片を 100 $\mathrm{MPa}, 3 \mathrm{~h}$ の条件で水熱酸化すると, $400^{\circ} \mathrm{C}$ でベーマ イト，コランダムとともに，500 $\mathrm{C}$ でコランダム， $x_{1}-$ $\mathrm{Al}_{2} \mathrm{O}_{3}$ とともに生成したと報告しているが, 本研究では $550^{\circ} \mathrm{C}, 10 \mathrm{MPa}, 24 \mathrm{~h}$ においてのみコランダムととも に現れた. Ervin ら ${ }^{16)}$, Krischner ら ${ }^{21)}$ の報告を Gitzen がまとめたアルミナー水系の状態図 ${ }^{35}$ によれば圧力 10 $\mathrm{MPa}$ 下では $320^{\circ} \sim 400^{\circ} \mathrm{C}$ で Reactive $\alpha-\mathrm{Al}_{2} \mathrm{O}_{3}, 400^{\circ} \mathrm{C}$ 以上では Autoclave $\gamma-\mathrm{Al}_{2} \mathrm{O}_{3}$ の生成領域である。これら の準安定相の生成領域は $\mathrm{X}$ 相, Y 相が生成し, 非晶質 化されて $\chi-\mathrm{Al}_{2} \mathrm{O}_{3}$, 更にコランダムへと変化していく水 熱条件と一致するので反応性に富んだこれらの準安定相 が硫酸アンモニウムと化合物を作り, これが分解する過 程で $\chi-\mathrm{Al}_{2} \mathrm{O}_{3}$ を生じたと考えられる。

一方, チ夕ニア成分は $700^{\circ} \mathrm{C}$ までアナターゼのみが 結晶化し，ルチルの生成は認められなかった。これも圧 力 $100 \mathrm{MPa}$ の場合とは異なる点であった。しかし，
Osborn ${ }^{36)}$ の報告したチタニアー水系でアナターゼからル チルへの変化は, $0.7 \mathrm{MPa}$ 程度より高圧では圧力によ る影響は小さい。したがって圧力 $10 \mathrm{MPa}$ の実験でル チルが生成しなかったのは, この場合は金容器に封入す る液体の充てん率が低い $\left(500^{\circ} \mathrm{C}\right.$ 以上では数 \% 程度 $)$ ことによる影響が考えられる。アナタ一ゼからルチルへ の相変化が溶解析出機構ならば十分な溶媒のないかぎり 変化は困難だからである。

\section{3 結晶化の時間依存性}

$500^{\circ} \mathrm{C}, 100 \mathrm{MPa}, 0 \sim 24 \mathrm{~h}$ の水熱条件で共沈試料を 結晶化させて反応時間の影響を調べた (図 10). チタ二 ア成分は温度が $500^{\circ} \mathrm{C}$ に達したとき既にアナターゼと して結晶化が始まっていたが, アルミナ成分は, まずベー マイトとして結晶化し，1時間後にはすべてコランダム となっていた。 また, 両成分は 4 時間後にはほぼ結晶化

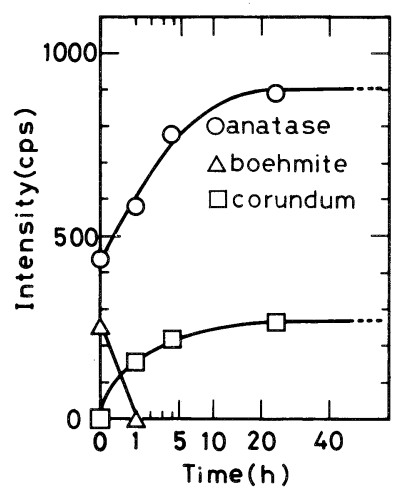

Fig. 10. Time dependence in hydrothermal crystallization of co-precipitated $\mathrm{Al}-\mathrm{Ti}$ hydrous oxides (including $\left.\left(\mathrm{NH}_{4}\right)_{2} \mathrm{SO}_{4}\right)$ at $500^{\circ} \mathrm{C}$, under $100 \mathrm{MPa}$. 
は完了するが，その後 20 時間にわたりわずかではある が結晶化が進行していた。したがって，少なくとも水熱 結晶化の初期の段階においてはアルミナ成分は，ベーマ イトを経てコランダムになると考えられるが，両相の共 存が見られないことからこの変化は非常に速やかに進行 するものといえる.

更に, $200^{\circ} \mathrm{C}, 100 \mathrm{MPa}$, の水熱条件で 0 24 h の水 熱結晶化を行ったところ，アルミナ成分はベーマイト， チタニア成分はアナターゼとして結晶化が進行したこと から，この両相は，非晶質相から直接に生成することが 確認された.

\section{4 共沈試料の洗浄処理による影響}

共沈試料中に含まれる硫酸アンモニウムの影響を調べ るため, 共沈試料を蒸留水やアルカリ溶液で洗浄した後 水熱処理を行った.

共沈試料を水で洗浄して沪過後 $120^{\circ} \mathrm{C}$ で 1 日乾燥さ せ，これを $500^{\circ} \mathrm{C}, 100 \mathrm{MPa}, 24 \mathrm{~h}$ の条件で処理すると
洗浄していない場合と同様コランダムとアナターゼが生 成した.しかし，10 MPa，24h の条件にすると $400^{\circ} \mathrm{C}$ では, 洗浄前の試料を用いた場合に比べ, X 相が減少し， ベーマイトが現れた（図 11）. $500^{\circ} \mathrm{C}$ では $\mathrm{Y}$ 相 $\left(\mathrm{NH}_{4} \mathrm{Al}\right.$ $\left.\left(\mathrm{SO}_{4}\right)_{2} \cdot 12 \mathrm{H}_{2} \mathrm{O}\right)$ が見られなくなり， $\chi-\mathrm{Al}_{2} \mathrm{O}_{3}$ のブロー ドな回折線と, $28 \sim 29^{\circ}$ 付近の強度の弱い回折線がこれ に代わった。これより硫酸アンモニウムはこの条件にお いては主にアルミナ成分の挙動に大きな影響を与えるこ とが分った.

共沈試料を水酸化ナトリウム $0.2 \mathrm{wt} \%$ 溶液で洗浄し て $500^{\circ} \mathrm{C}, 100 \mathrm{MPa}, 24 \mathrm{~h}$ で水熱結晶化させると，洗浄 していない場合と同様アナターゼとコランダムが生成し た。しかし，1 wt \% あるいは $10 \mathrm{wt} \%$ 溶液で洗浄した 場合は $\mathrm{pH}$ が約 14 まで上がり，生成物はあまり結晶性 のよくない粉末 X 線回折図形を与えた (図 12).これ はBayer ら ${ }^{37)}$ が報告した $\mathrm{Na}_{2} \mathrm{Ti}_{2} \mathrm{Ti}_{6} \mathrm{O}_{16}{ }^{38)}$ と考えられる. アルミナ成分を含む結晶性生成物が見られないのはアル

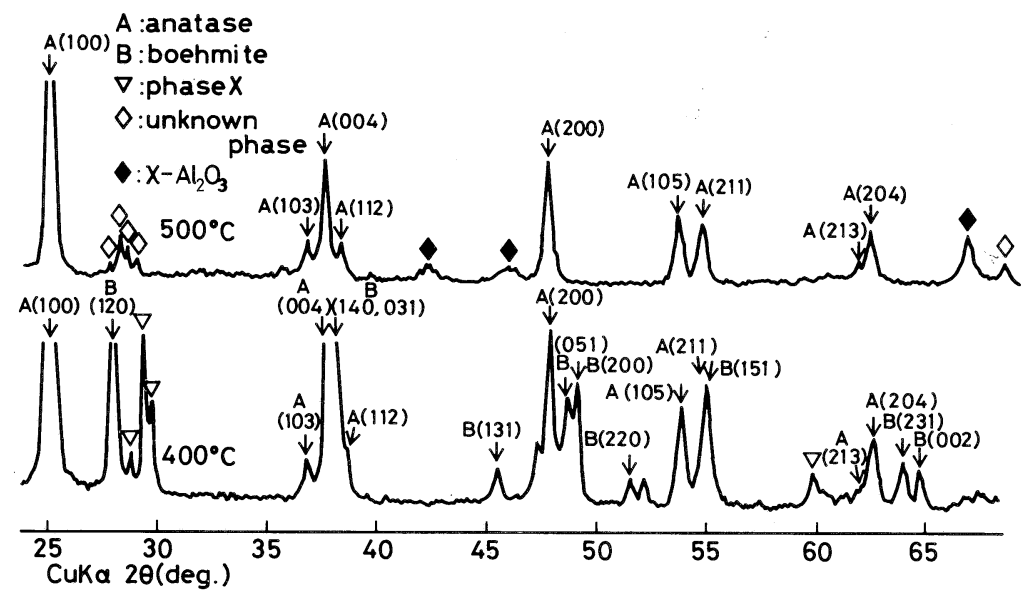

Fig. 11. Effect of washing with $\mathrm{H}_{2} \mathrm{O}$ to co-precipitated Al-Ti hydrous oxides (including $\left.\left(\mathrm{NH}_{4}\right)_{2} \mathrm{SO}_{4}\right)$ on hydrothermal crystallization at $400^{\circ}, 500^{\circ} \mathrm{C}$, under $10 \mathrm{MPa}$, for $24 \mathrm{~h}$.

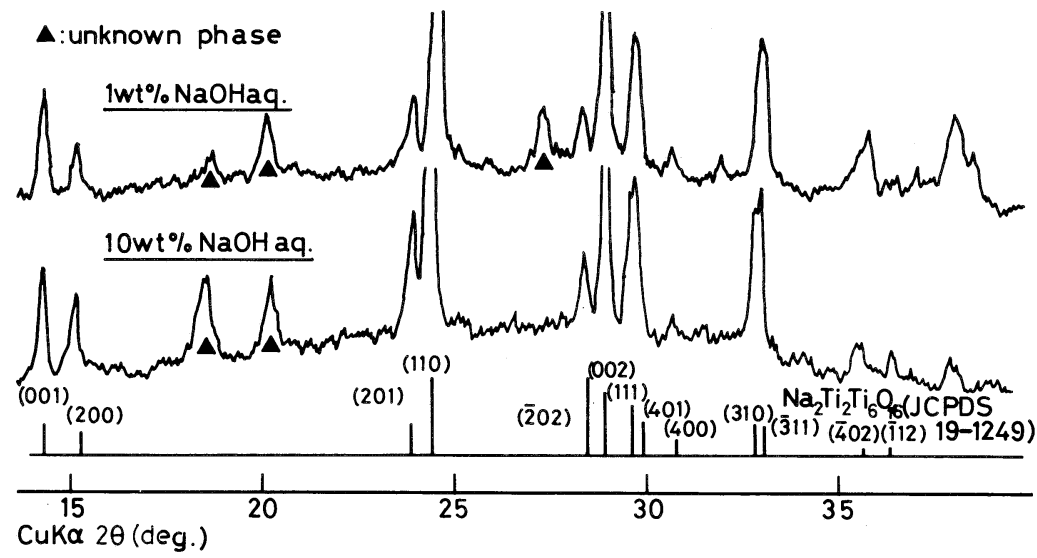

Fig. 12. Effect of washing with $\mathrm{NaOH}$ solutions to co-precipitated Al-Ti hydrous oxides (including $\left.\left(\mathrm{NH}_{4}\right)_{2} \mathrm{SO}_{4}\right)$ on hydrothermal crystallization at $500^{\circ} \mathrm{C}$, under $100 \mathrm{MPa}$, for $24 \mathrm{~h}$. 


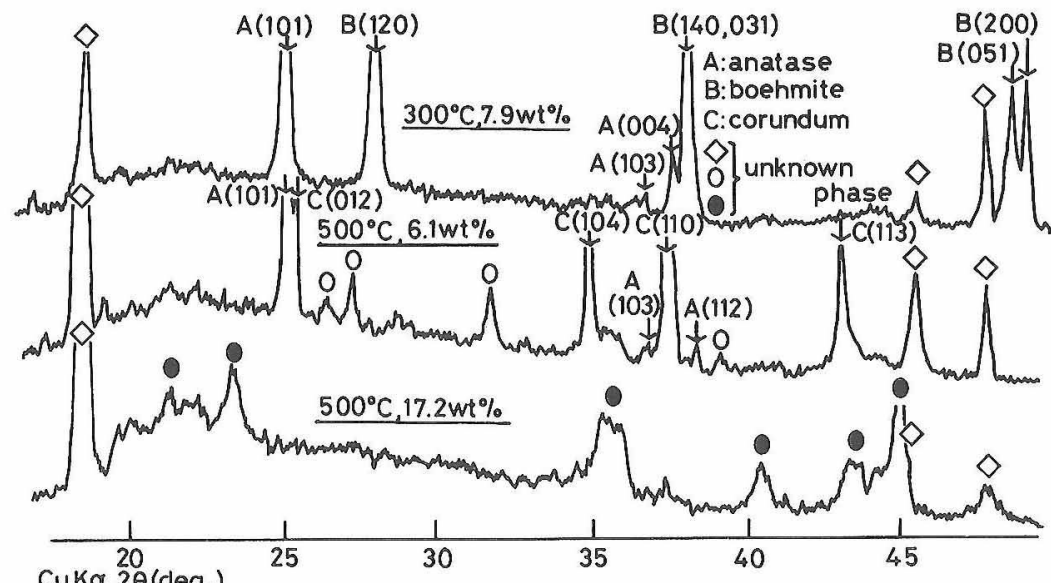

Fig. 13. Hydrothermal crystallization of co-precipitated Al-Ti hydrous oxides (including $\left.\left(\mathrm{NH}_{4}\right)_{2} \mathrm{SO}_{4}\right)$ with $\mathrm{LiOH}$ solution at $300^{\circ}, 500^{\circ} \mathrm{C}$, under $100 \mathrm{MPa}$, for $24 \mathrm{~h}$.

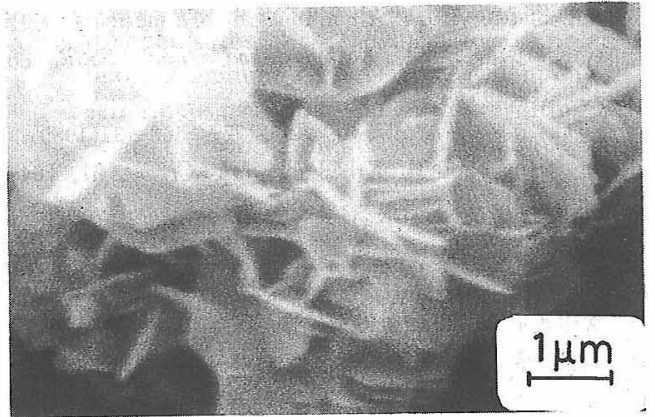

Fig. 14. Lithium-titanium-oxide crystals crystallized hydrothermally from hydrous oxides (including $\left.\left(\mathrm{NH}_{4}\right)_{2} \mathrm{SO}_{4}\right)$ with 17.2 wt $\% \mathrm{LiOH}$ solution at $500^{\circ} \mathrm{C}$, under $100 \mathrm{MPa}$, for $24 \mathrm{~h}$.

ミン酸イオンとして溶解したためと思われる.

次に，水酸化リチウム 6 wt \% 溶液を加えて $500^{\circ} \mathrm{C}$, $100 \mathrm{MPa}, 24 \mathrm{~h}$ で共沈武料を水熱結晶化させると，ア ナターゼ、コランダムとともに，CuK $K \alpha 2 \underline{\bar{\theta}}=18.5^{\circ}$ 付 近に強い回折線を持つ $Z_{1}$ 相が現れた（図 13）。この相 の回折線の幾つかは 8 wt \% 溶液を用いて $300^{\circ} \mathrm{C} て ゙$ 結晶 させたときにもアナターゼやベーマイトとともに出現し た. 更に，水酸化リチウムの濃度を $17.2 \mathrm{wt} \%$ にて $500^{\circ} \mathrm{C}$ で結晶化させた場合にもこの $Z_{1}$ 相は見られるが, アナターゼやコランダムに代わって結晶性の悪い回折線 を示す $Z_{2}$ 相が加わっている。これらの相 $\left(Z_{1}, Z_{2}\right)$ は リチウムーチタンー酸化物と思われるが同定はできなかっ た. SEM 観察では，この $500^{\circ} \mathrm{C}$ の武料は板状の粒子で あった（図 14）， Z 相の回折線で $18.5^{\circ}$ にだけ鋭く強い ものが現れるのはこの形状による粒子の配向も考えられ 万。

一方，水酸化アンモ二ウム $25 \mathrm{wt} \%$ 溶液を加えて $500^{\circ} \mathrm{C}, 100 \mathrm{MPa}, 24 \mathrm{~h}$ で結晶化した場合は，水を用い
た場合し同じくコランダムとアナターゼしか生成しな かった。またアルミナ成分が反応しやすい状態にあると 思われる $400^{\circ} \mathrm{C}, 10 \mathrm{MPa}, 24 \mathrm{~h}$ の水熱条件下でフッ化 ナトリウム 4 wt \% 溶液を用いて，水で洗浄した武料を 結晶化させても水を用いた場合と同じであった。した がって，この条件下でアルミナやチタニアの挙動に影響 するのは塩基性溶液中のナトリウムやリチウムのような 陽イオンであろう.

3.5 水熱条件下におけるチタン酸アルミニウムの分 解

チタン酸アルミニウム $\left(\mathrm{Al}_{2} \mathrm{TiO}_{5}\right)$ はアルミナーチタ 二ア系唯一の中間化合物であるが，常圧下では $1250^{\circ} \mathrm{C}$ 以上でのみ安定相であり空気中 $800^{\circ} \sim 1200^{\circ} \mathrm{C}$ でコラン ダムとルチルに分解する ${ }^{39 !}$.

本研究でも複合酸化物は生成しておらず，チタン酸ア ルミニウムが水熱条件下では安定でなく，アルミナとチ タニアに分解することを示唆している．これを確認する ために共沈試料をアークイメージ炉で融解して合成した チタン酸アルミニウムを水熱処理した。

$500^{\circ} \mathrm{C}, 100 \mathrm{MPa}, 24 \mathrm{~h}$ で処理するとチタン酸アルミ ニウムは完全に分解してコランダムとアナターゼとなっ た。すなわちチタン酸アルミニウムは水熱条件下でも安 定ではないことが分ったが，ルチルではなくアナタ一ゼ が生成している点が空気中の分解亡異なっている。水熱 条件下でルチルがアナターゼに変化することはこれまで 報告がほとんよ゙なく，本研究でも観察されていないので アナターゼはチタン酸アルミニウムから直接生成したと 思われる。

4. 総括

アルミニウムーチタン混合硫酸塩溶液からの共沈水和 物に水熱結晶化法を適用してその生成物を調ベ，混合微 
粉体の生成を検討した.

(1) 圧力 $100 \mathrm{MPa}$ 下においては, ベーマイトが $100^{\circ} \sim 400^{\circ} \mathrm{C}$, コランダムは $500^{\circ} \mathrm{C}$ 以上で生成し，アナ ターゼは $500^{\circ} \mathrm{C}$ 以上でルチルへ変化していく.

(2) 圧力 $10 \mathrm{MPa}$ 下においては, ベーマイトが $100^{\circ} \sim 300^{\circ} \mathrm{C}$, コランダムは $600^{\circ} \mathrm{C}$ 以上で生成し, $400^{\circ}$ $500^{\circ} \mathrm{C}$ では硫酸アンモニウムとアルミナの化合物, 550 ${ }^{\circ} \mathrm{C}$ では結晶性の悪いコランダムと $\chi-\mathrm{Al}_{2} \mathrm{O}_{3}$ が生成する.

（3）アナターゼ,ベーマイトは非晶質から結晶化し, ルチルはアナターゼから，コランダムはベーマイトから 生成する。

（4）アルミナーチタニア系の水熱結晶化では，用い る鉱化剤溶液によってアルミナやチタニア以外の化合物 が生成する。

（5）本実験の条件下においては，アルミナーチタ二 ア複合酸化物は認められず，チタン酸アルミニウムは分 解することが分った。

謝 辞 X 線粉末解析について東京工業大学工業材料研 究所 (現在, 名古屋工業大学害業技術研究施設) の虎谷秀穂博 士より御助言を頂いた。 また，本研究の費用の一部は文部省科 学研究費特定研究 (No.57116006) によったのでここに感謝の 意を表します.

\section{文献}

1) S. M. Lang, C. L. Filmore and L. H. Maxwell, J. Res. Natl. Bur. Stand., 48, 298-312 (1952).

2）前田 嬢, 水野正雄, 野口長次, 名工試報告, 5 , 620-23 (1956).

3）永廣彰夫, 御代健次郎, 旭硝子研報告, 3，148-55 (1953).

4）加藤悦朗, 加藤隆治, 大門啓志, 第 20 回窯業基礎討論会 要旨集, A 2-06 (1982).

5）大矢 豊, 浜野健也, 中川善兵衛, 窯協, 91, 289-97 (1983).

6) M.S. Gani and R. McPherson, J. Mater. Sci., 15, 1915-25 (1980).

7）徳永幸男, 陶山容子, 加藤昭夫, 日化，1982，1758-62.

8）吉村昌弘, 菊川信也, 宗宮重行, 窯協, 91, 182-88 (1983).

9) S. Sōmiya, M. Yoshimura and S. Kikugawa, "Preparation of Zirconia-Alumina Fine Powders by Hydrothermal Oxidations of $\mathrm{Zr}$-Al Alloys", Proceeding the 19th University Conference on Ceramic Science, Emergent Process Methods for High Technology Ceramics, Nov. 8-10 1982, North Carolina State University, Raleigh, N.C., Materials Science Research Vol.17, 155-66, Ed. R.F. Davis, H. Palmour III and R. L. Porter, Plenum Pub., New York (1984).

10) H. Toraya, M. Yoshimura and S. Sōmiya, "Preparation of Fine $\mathrm{Al}_{2} \mathrm{O}_{3}-\mathrm{HfO}_{2}$ Mixed Powders by Hydrothermal
Oxidation”, Proceeding 2nd International Conference on the Science and Technology of Zirconia, Sttutgart, June 21-23, 1983, Science of Ceramics Vol.11, Ed. N. Claussen, the American Ceramic Society, in press.

11) E. Tani, M. Yoshimura and S. Sōmiya, J. Am. Ceram. Soc., 64, C-181 (1981).

12) E. Tani, M. Yoshimura and S. Sōmiya, J. Am. Ceram. Soc., 66, 11-14 (1983).

13）宗宮重行，“ジルコニアセラミックス I”，内田老鶴圃 (1983) p. 1-19.

14) A. W. Laubengayer and R.S. Weisz, J. Am. Chem. Soc., 65, 247-50 (1943).

15) P. W. Cooke and J. N. Haresnape, Trans. Farad.Soc., 43, 395-98 (1947).

16) G. Ervin and E. F. Osborn, J. Geol., 59, 381-94 (1951).

17) R. Roy and E. F. Osborn, Am. Mineralogist, 39, 853-55 (1954).

18) J.W. Newsome, H. W. Heiser, A.S. Russell and H. C. Stumpf, “Alumina Properties, Tech. Paper No.10" (Second Revision) Aluminum Co. of America (1960).

19) N. K. Druzhinina, Doklady Akad. Nauk. SSSR, 88, 133-34 (1953).

20) G. C. Kennedy, Am. J. Sci., 257, 563-73 (1959).

21) K. Torkar and H. Krischner, Mh. Chem., 91, 764-73 (1960).

22）太田敏孝, 山井 嚴, 斎藤 肇, 窯協, 87, 375-82 (1979).

23）太田敏孝, 山井 嚴, 斎藤 肇, 窯協, 87, 512-19 (1979).

24）太田敏孝, 山井 篇, 斎藤 肇, 窯協, 88, 460-68 (1980).

25）井本文夫，金子正治，工化，74，591-97 (1971).

26）泉 富士夫, “水熱条件下におけるルチルとアナタ一ゼの 晶出”, 科学技術庁無機材質研究所研究報告書第 19 号 (1979) p. 4-12.

27）藤木良規，“酸素分圧制御下におけるアナターゼの水熱合 成と相転移”，科学技術庁無機材質研究所研究報告書第 19 号 (1979) p. 12-18.

28) H. Toraya, M. Yoshimura and S. Sōmiya, J. Appl. Crystallogr, 16, 653-57 (1983).

29）佐藤太一, 小沢房治, 生駒修治, 真空理工ジョーノル, 8, 10-16 (1979).

30）吉村昌弘，菊川信也，宗宮重行，粉体及び粉末冶金，30, 207-10 (1983).

31）黒崎章人, 岡崎 進, 日化, 1976, 1816-21.

32）舟木好右衛門, 佐伯雄造, 工化，59，1297-1300 (1956).

33）舟木好右衛門，佐伯雄造，工化，59，1295-97 (1956).

34) JCPDS File No.7-22.

35) “Alumina as a Ceramic Material", Ed. W.H. Gitzen, Am. Ceram. Soc. Inc., Ohio (1970) p. 22.

36) E. F. Osborn, J. Am. Creram. Soc., 36, 147-51 (1953).

37) G. Bayer, O.W. Flörke, W. Hoffmann and H. -J. Scheel, Glastechn. Ber., 39, 242-61 (1966).

38) JCPDS File No. 19-1249.

39）浜野健也, 耐火物, 27, 520-27 (1975). 